\title{
LETTER
}

\section{Response to 'T-helper 17 cell cytokines and interferon type I: partners in crime in systemic lupus erythematosus?'}

\author{
Sebastian Dolff ${ }^{*}$, Wayel H Abdulahad ${ }^{2}$ and Cees GM Kallenberg ${ }^{2}$
}

See related research by Brkic et al., http://arthritis-research.com/content/16/2/R62 and

related letter by Brkic et al., http://arthritis-research.com/content/16/3/410

We read with great interest the article by Brkic and colleagues in a recent issue of Arthritis Research \& Therapy [1]. In that study, the authors investigated the distribution of $\mathrm{T}$ helper $(\mathrm{Th})$ subsets which produce IL-17A, IL-17 F, IL-21, and IL-22 in patients with systemic lupus erythematosus (SLE) in relation to their genetic IFN type I signature. Patients with an IFN type I-positive signature showed increased percentages of IL-17A- and IL-21-producing $\mathrm{CCR}^{+}{ }^{+} \mathrm{T}$ cells. From these results, the authors conclude that IFN type I cells co-act with Th17 cytokines in the pathogenesis of SLE. Surprisingly, they excluded $\mathrm{CD} 25^{+} \mathrm{T}$ cells from their analysis. In a previous study, we showed that Th cells from SLE patients expressing $\mathrm{CD} 25^{\text {med }}$ and CD25 $5^{\text {high }}$ are also able to produce IFN- $\gamma$ and IL-17A [2]. Therefore, it would be relevant to assess cytokine expression in $\mathrm{CD} 4^{+} \mathrm{CD} 25^{+} \mathrm{T}$ cells from IFN type I-positive and IFN type I-negative SLE patients. Furthermore, it should be proven that the genetic signature is solely responsible for the increased IFN production by Th cells. In addition, their finding that $\mathrm{CCR}^{+}{ }^{+} \mathrm{T}$ cells are capable of producing IL-21 indirectly confirms our previous observation that IL- $17^{+} \mathrm{T}$ cells are a main source of IL-21 in patients with SLE [3]. Possibly, IL-21 is orchestrating the Th1/Th17 axis.

Finally, we agree that there might be a co-activity between IFN-I- and IL-17-producing cells as described by Brkic and colleagues. However, considering our findings that $\mathrm{T}$ cells with a regulatory phenotype are able to produce IFN- $\gamma$ and IL-17A in patients with SLE, we suggest that primarily the plasticity of $\mathrm{T}$ cells is altered in patients with SLE [4].
Abbreviations

IFN: Interferon; IL: Interleukin; SLE: Systemic lupus erythematosus; Th: T helper.

\section{Competing interests}

The authors declare that they have no competing interests.

\section{Authors' contributions}

All authors contributed to the interpretation of data. SD drafted the manuscript. All authors read and approved the final manuscript.

\section{Author details}

'Department of Nephrology, University Hospital Essen, University Duisburg-Essen, Hufelandstr. 55, 45122 Essen, Germany. '2Department of Rheumatology and Clinical Immunology, University Medical Center Groningen, University of Groningen, Hanzeplain 1, 9713 GZ, Groningen, The Netherlands.

\section{Published: 09 Jun 2014}

\section{References}

1. Brkic Z, Corneth OB, van Helden-Meeuwsen CG, Dolhain RJ, Maria NI, Paulissen SM, Davelaar N, van Hamburg JP, van Daele PL, Dalm VA, van Hagen PM, Hazes JM, Versnel MA, Lubberts E: T-helper 17 cell cytokines and interferon type I: partners in crime in systemic lupus erythematosus? Arthritis Res Ther 2014, 16:R62

2. Dolff S, Bijl M, Huitema MG, Limburg PC, Kallenberg CG, Abdulahad WH: Disturbed Th1, Th2, Th17 and Treg balance in patients with systemic lupus erythematosus. Clin Immunol 2011, 141:120-197.

3. Dolff S, Abdulahad WH, Westra J, Doornbos-van Der Meer B, Limburg PC, Kallenberg CG, Bijl M: Increase in IL-21 producing T-cells in patients with systemic lupus erythematosus (SLE). Arthritis Res Ther 2011, 13:R157.

4. Koenen HJ, Smeets RL, Vink PM, van Rijssen E, Boots AM, Joosten I: Human CD25highFoxp3pos regulatory T cells differentiate into IL-17-producing cells. Blood 2008, 112:2340-2352.

\subsection{6/ar4576}

Cite this article as: Dolff et al:: Response to 'T-helper 17 cell cytokines and interferon type I: partners in crime in systemic lupus erythematosus?'. Arthritis Research \& Therapy 2014, 16:409

\footnotetext{
* Correspondence: sebastian.dolff@uk-essen.de

'Department of Nephrology, University Hospital Essen, University

Duisburg-Essen, Hufelandstr. 55, 45122 Essen, Germany

Full list of author information is available at the end of the article
} 